http://jmscr.igmpublication.org/home/

ISSN (e)-2347-176x ISSN (p) 2455-0450

crossref DOI: https://dx.doi.org/10.18535/jmscr/v9i1.44

Journal Of Medical Science And Clinical Research

IGM Publication

An Official Publication of IGM Publication

\title{
Socio-economic changes of the Lodha Tribes in the era of Globalization: A study in the tribal villages of the Jangalmahal
}

\author{
Authors \\ Madhumita Setua ${ }^{1}$, Dr Sajijul Islam ${ }^{2}$ \\ ${ }^{1}$ Research Scholar, Dept. of History, Vidyasagar University \& State Aided College Teacher, Dept. of \\ History, Midnapore College, Midnapore, West Bengal \\ ${ }^{2}$ Assistant Professor, Department of Commerce, Srikrishna College, Bagula, Nadia, West Bengal
}

\begin{abstract}
The Lodha Tribes carry a unique culture among the tribal people of the West Bengal. They are one of the three tribes of West Bengal who belong to the Primitive tribal group. Sometimes they have known as Kheria or Shabar people. They live in many districts of West Bengal but the Jangalmahal areas of the Bankura (4.2\%), Purulia (3.0\%), and Medinipur (undivided, 43.1\%) districts they are more numerous. Now they work as farmers and laborers, but earlier their main livelihood was collecting and hunting from the jungle. As a result of globalization and the decline of the jungle, their society has undergone many changes. The main purpose of this paper is to discuss what has changed in their society, culture, economy, and lifestyle as a result of globalization. And also analyze the impact of globalization on their rituals, customs, dressing patterns, and occupations. Recently it has been noticed that non-tribal impact is very much increasing in the Lodha society. Gradually they are falling into the trap of craving for the objects of consumerism. Their material needs have increased, but poverty has not declined. As a result, many antisocial acts and other disasters are appearing in their society. They are suffering from illness due to drinking alcohol, malnutrition and moral degradation. Again, with globalization, some positive things have happened in their society. With this, their marginality has decreased. More children of them are now joining with education, health services have improved and knowledge about the equipment/ gadgets has increased.
\end{abstract}

Keywords: Lodha, Tribe, Globalization, Culture, Life-style, Economy, Jangalmahal.

\section{Introduction}

Nowadays, the word globalization is a very familiar word. It becomes famous in the last decade of the previous century, and its prevalence in the present world has been increasing steadily. This process continues to affect people of all classes within the global society and is deeply involved with people's lives and livelihoods. As a result, the known world of people is changing very rapidly. In general means, globalization is a global situation where the world becomes borderless in such away. As a result, the economy of all the countries will be opened and trade will be free. Gradually, these open markets will have an impact on other dimensions of human life like communication, environment, culture, etc., and they also will be free. Globalization is the new world order is a situation that cannot be prevented. It was referred to emerging of an international network, belonging to an economical and social 
system. ${ }^{1}$ The use of the term globalization began in the 1960s. After the cold war, the world began to be used to describe the word becoming more interdependent in its economic and informational dimension. ${ }^{2}$ as the world becomes more open to the effects of globalization, the effects of it continue to be felt in human life.

Lives of tribal people are not beyond the impact of globalization. Instead, they are almost losing their individuality by suddenly entering of globalization in their own world. Tribe, who are a social group often of related families who lives together, sharing the same language, culture, and history, especially those who do not live in towns and cities, ${ }^{3}$ globalization has had a profound impact on their lives. India has a large number of tribal groups. Tribal population constitutes $8.6 \%$ of India's total population or according to the census of 2011, the population is 104 million.

Lodha tribe is one of the primitive tribes of West Bengal. According to the 2001 census report, their total population was 84,966 . In West Bengal, the majority of the population is seen in the districts of Medinipur (43.1\%), Jalpaiguri (34.9\%), Bankura (4.2\%) and Purulia (3.0\%). The Jangalmahal areas of Medinipur, Bankura, and Purulia are their original homeland. Jalpaiguri is not their homeland because they went here as migrant workers. The Lodha people belong to the Austro-Asian language group. Risley describes them as a part of the Bhumij Tribe. ${ }^{4}$

The British government identified them as a criminal tribe. ${ }^{5}$ However, there was no basis for giving this humiliating blow to this tribe. After independence, the government of India declared them as 'De notified tribe' in 1952. The primitive tribal group is a category of tribes which comprises 75 tribal groups. These groups are the most socio-economically backward tribal group of India. Three tribal groups from West Bengal have been listed as primitive tribal group, these are Lodha, Toto, and Birhor. ${ }^{6}$ According to the Indian constitution, the Lodha group belongs to the scheduled tribes. According to the census of 2001, it was found that $9.8 \%$ of them were farmers and
$45.5 \%$ of the people's occupations were agricultural laborers. The number of farmers is low because they do not have their own land so they have to work as agricultural laborers. In the seventies, when the government tried to give them some agricultural land but the amount of land was very low and it did not go to the lands of every one of their society. So Lodha of the Jangalmahal is still dependent on the forest for their living. The literacy rate among the Lodha is very low, only $34.8 \%$. Hunger and poverty still unlimited among them and they have no habitable homes. The education situation of women is also worse in society. The first female graduate of Lodha society was Chuni Kotal ( 1985). Lodha are not a good farmer like Santal, Munda or Mahatas but they knew the forest very well. They had an immense knowledge of trees, herbs and folk medicines. Various titles can be seen in the Lodha's, like, Bhakta, Digar, Kotal, Nayek, Ahora, Bhuiya, Shabar, etc. they worship their own village gods, such as Boram, Goram, Jugin, Shitala, Chandi. Approximately $10 \%$ of the Lodha people's religion is Christianity. The rest are considered as Hindus according to the census although they worship nature just like other tribal groups. This information on the Lodhas indicates that they had a unique cultural heritage. But as an affects of globalization, their own uniqueness is gradually changing and their reservation is also slowly diminishing.

\section{Methodology}

This paper is based on primary and secondary data sources. Primary sources are mainly based on the interviews of elderly persons and field surveys and the secondary sources are the past field study, relevant books, journals, census data, and reports. Data collection is based on a random sampling technique from the Lodha tribe respondents.

\section{Objectives}

1. To focus the significance of the tribal culture in the present day scenario. 
2. To study the economic, social and cultural aspects of Lodha tribes.

3. To examine the impact of globalization on the socio-economic conditions of Lodhas. And

4. To suggest appropriate measures to restore their culture.

\section{Socio-cultural aspects}

“ নধা নিল কুঢ়ারটি .... নধানি নিল ঝড়া” that is, the Lodha boy has the ax in his hand and the girl holds a basket. This is a real picture of their daily lives. This implies that their livelihood depends on the labor of both husband and wife. They live in small villages on the outskirts of the forests. In the village, they live in small mud cottages. In these villages, all the people are lived in a friendly way. A family of Lodha's is formed with husband, wife, children, and their old parents. In each village, there is a ' Morol' or 'Mukhiya'( Village Headman) who gives proper advice to the people of the village. Every village has a village deity who protects the village from evil forces. Apart from 'Mukhiya' in Lodha society, some other important people are Dehari ( the priest of village deity), Bostom( doing various important rituals) and Napit ( helps to purity). Presently some changes have been seen in their social structure by the impact of globalization. Many of them are leaving villages and moving to cities or other states in search of better livelihoods. They are coming out from the joint family and of the 'Mukhiya's regime, so their tribal character is also changing. They are losing the ownness of their religious factors and the influence of Hinduism is increasing.

\section{Marriage System}

One of the important social events of the Lodha society is marriage. They have their own wedding rituals. They have long been associated with this unique feature with their marriage. In their society, the bride and groom are usually met with each other in their workplace or Village Theater or fair before marriage and choose each other without other influences. There was a tradition of bride dowry which was paid by the groom. At the present time, they meet through the matchmaker or through social media and mobile phones. However, they still adhere to some of the rituals, one of them is to bring the 'Shaora Tree's soil to the marriage place. In their marriage, the daughter's maternal uncle promoted the marriage and there is a ritual of exchanging wreath between the bride's brother and the groom. 'Bostom' of the village is completed the marriage ceremony of Lodha society. ${ }^{7}$ The impact of globalization is very much affected their selecting method and the luxury of the wedding has grown a lot. Playing the sound box loudly at the wedding and use of latest clothes is becoming more relevant now.

Children: In pregnancy times of a woman of their society, there are many rituals and rules. The mother has to make changes to her diet and some foods were forbidden to her like sour foods. Herbal medicines are provided by the folk healers. She also wears threads, stone and other sacred things for avoiding evil eyes of bad forces. The baby was born under the supervision of the midwife and the baby's umbilical cord was cut with a bamboo scissor. They had no idea about family planning in their society. But at present, their tendency to go to the hospital has increased. ${ }^{8}$ The appointment of 'Asha' workers in the villages has made them more aware of health. So their overall health has improved than before.

Eating Habits: the Lodha people's main food was the meat which they collected from the hunting and rice (although they did not eat rice every day because of their poverty, then they used to collect grass seeds) they also collected fruits, vegetables and wild potatoes from the forests. Over times, these food habits have been changed. Now rice has become much more accessible to them. They have receiving domestic and foreign help which is an impact of globalization. They eat a kind of rice beer with drunk it provided them their body strength. But nowadays their youth become addicted to malicious alcohol drinking and other harmful addiction which are coming from outside of their society. This is certainly one of the bad impacts of globalization. 
Dressing Patterns: the effect of globalization has been seen on the clothes of the Lodha. Previously, the main cloth of their men was a tiny 'dhoti' ( a piece of cloth) which they wore in the lower part. And women wear a saree. The seasonal changes do not make very much difference in this picture. But now in their villages, it is seen that the youths are trying to dress like a movie or daily soap artist. The touch of modernity is also noticed in their hairstyles. ${ }^{9}$

Health: knowledge about herbal medicines among the Lodha is much higher than other tribal groups because they know the forests very well. So they used to cure their minor illnesses through their herbal knowledge. As a result of globalization, the young people of their society are almost forgetting this knowledge about herbs. Now gradually they depend more and more on the hospitals and allopathic doctors. However, they still have a believer to blame evil deities as the cause of diseases.

Education: the condition of education in Lodha society was very bad. Yet many people in their society are totally uneducated. But now the number of Lodha school students has increased due to government initiatives such as mid-day meals, kanyashree, etc. however, despite the increasing number of students in the school; their position in higher education is still miserable. ${ }^{10}$

\section{Economic Condition}

Lodha's economy was mainly dependent on forests. Since they live literary next to the forest, the importance of forests in their lives is similar to those living in the adjacent forests. They collected their main foods from forests. Generally, the economy of Lodha's depends on the following things;

Hunting: a large part of the society of Lodha lives on the hunting. It had also a great role in their cultural life. During a special time of the year, they celebrate the festival of hunting. The animals they are hunting are usually rabbits, wild cats, deer, birds, and iguana. By eating the meat they hunt, they meet the food shortages and their needs of the protein. Sometimes they sell the animal's skin in the markets. Now, due to globalization and the decline of forest animals, they are no longer dependent on hunting for food. The impact of globalization increasing their perception of the wider market and some of them are falling into the trap of poacher world.

Food Collecting: besides hunting, they collect various foods from the jangle that helps their economy too. This collection includes plant roots (wild potato, various roots), buds, branches, the soft stem of plants, leaves, flower seeds, mushrooms, etc. they used these things for daily foods and income money by selling extra ingredients in the markets.

Secondary things collecting from the forests: They collected various other products from the forests. The Lodha people collect these products for personal use and also for sale in the markets. These are oil, medicinal plants, resins, bamboo, cane, honey, wax, shal leaf, tree bark lacquer, etc. their economy is very much dependent on these.

Fuel Collection: Dry woods are their main fuel of cooking. They collecting tree branches from the forests and dried them in light of the sun. The Lodha women from Jangalmahal collect woods from the jungle and sell it as fuel so that they earned some money for livelihood.

Animal Husbandry: An important aspect of their livelihood is animal husbandry. Many domestic can be seen in almost every house of the Lodha. It affects their economy significantly. These are the main animals and birds they feed on; goat, hen, cow, buffalo, lamb, pig, duck, etc. from the jungle, they get animals feed.

Agriculture: Lodha people are associated with agriculture but most of them not have their own land. So they work as agricultural labor on other's land. In this way, they are able to make some money during the farming season. Earlier, they used to cut some trees of the jungle and prepare the land for agriculture but with the forest act, they no longer have this right. So their economy is not as dependent on agriculture as the rest of the tribes. 
Handicrafts: there is not very much craftsman in Lodha society. Among them, bamboo basket making and leaf plate industry are more commonly seen. The women make some income by doing making whisk and knitting mats. This kind of art is very domestic in nature.

But now, with the impact of globalization, the features of their economy are changing. With the discovery of a wider world, the youth generation no longer wants to confine themselves to the conservatism of their society. Their material needs are increasing and they are looking for other occupations to meet the demand for luxury. Many of them are going to other states in search of jobs in hopes of making extra money. Those who are unable to go are getting involved in anti-social activities like liquor business and robbery. They have forgotten their roots for material needs. Most of them do not select the other way, which is education.

\section{Conclusion}

In the present scenario, the Lodha culture, social system, and economic system are getting eroded. The impact of globalization has seen many changes in their youth society. The greed of the luxury of the larger world has attracted them. Mobile phones, televisions, motorcycles are the very common thing to them now. But it is not fair to believe that their poverty is gone. They are using dishonest ways to fulfill these needs that do not fit with the moral values of their society. They are no longer willing to associate with farming and animal husbandry. Also, they are unable to receive the benefits of governments and the constitution for lack of knowledge and proper education.

So finally, it can be said that the impact of globalization is inevitable and like other societies, it will also have an impact on Lodha society. But if Lodha people try to use the benefits of globalization in other aspects like education and health and strive to be modern in keeping with their own traditions then it will be possible to prevent this deterioration of their society. At the same time, the government will have to pay a proactive role to raise awareness.

\section{References}

1. A.G. Hopkins(ed) 2004, globalization in world history, London, Norton

2. Kanchan Roy(Ed), Education And Health Problems In Tribal Development: A Study Of National Integration, Concept Publishing House, New Delhi, 2008,

3. .A.K. Das, M. K. Raha, S. K. De, Tribal Situation In West Bengal. Firma Klm Privat Limited, 1990, Kolkata. P110.

4. Padmaja Sen(Ed), Changing Tribal Life: A Socio- Philosophical Perspective. Concept Publishing Company, New Delhi, 2003, Pp74-75.

5. Dr. Mrinal Chandra Haldar. Jonojati Lodha; Ekti Lokosanskritik Nirikha. Pustak bipani , 2014, Kolkata.

6. H.H. Risley. The Tribes And Caste Of Bengal, vol 1,2.

7. J. Cyril Kanmony(Ed), Dalits and Tribes of India, Mittal Publication, New Delhi, 2010.

8. Santosh Rana, Kumar Rana, Paschimbonge Dalit o Adibasi, Camp Publication, 2009,

9. Sumahan Bandapadhay, Prosongo Adibasi, Offbeat Publication, 2012, Kolkata.

10. P. K. Bhowmik, Lodha's of West Bengal: A Socio-Economic Study, Punthi Pustak 1963. 